\title{
Potters Kiln Bricks: Using Manual Brick Making Machine
}

\author{
Maikudi Umar Ali Inuwa \\ Fine And Applied Arts Dept., Federal College Of Education Kano- Nigeria
}

\begin{abstract}
Bricks production is of vital importance for the sustenance and development of Nigerian ceramic potteries, ceramic tiles, red bricks and glass industries. Ceramic brick is the unit of kiln construction which without, ceramic production is impossible. Despite the availability of raw materials for potters kiln brickmaking locally everywhere in this country, little has been done in terms of investigating and designing standard brickmaking processes in Nigeria. Right from the inception of soft mud brickmaking method which is the main method for local production of potters kiln bricks has been associated with some problems. The production of brick (handmade brick) is found to be very slow, time consuming and labour intensive. This method of production is associated with irregular shapes due to its poor compaction capacity which affect lifespan of the kiln and insolation performance as well. Hence, there is need to attempt to produce potters kiln bricks with manual brickmaking machine which will minimize these problems. These manual bricks making machine was made primarily to produce concrete cement brick. The successful completion of this research will therefore lead to replacement of the soft mud brickmaking process, and also substitute the high-tech motorized Compressed Earth Brick (CEB) machine, with locally constructed brickmaking machine it will also improve the quality of the thermal and mechanical properties of the brick in terms of shape and form using the standard compaction pressure which is equivalent to American Society for Testing and Materials (ASTM) stabilization standard. This will also help in reducing the cost of buying imported ceramic brick at a higher rate, as well as create selfemployment opportunities and support the growth of contemporary pottery and ceramic entrepreneurship programme in Nigeria.
\end{abstract}

Keywords: Kiln, brick, pottery, refractory

DOI: $10.7176 / \mathrm{JEP} / 10-11-04$

Publication date: April $30^{\text {th }} 2019$

\subsection{Introduction}

Potters kiln brick is a block of refractory ceramic material fired to a very high temperature and usually smaller than the normal concrete block, used in lining furnaces, kilns, fire boxes, and fire places. A refractory brick is built primarily to withstand high temperature. Bricks have smaller units either solid or with small cores usually made of clay. The fired solid brick material density is approximately $1900 \mathrm{~kg} / \mathrm{m} 3$ while the perforated brick is between $1400-1500 \mathrm{~kg} / \mathrm{m} 3$. Refractories are inorganic nonmetallic material which can withstand high temperature with slight physical changes while remaining in contact with molten slag, metal and gases, Steven (2017). In view of the facts that refractories are produced to meet range of differing processing conditions, the refractory range incorporates fired, chemically and carbon bonded materials that are made in different combinations and shapes for diversified applications (Gupta, 2017).

The term "refractory" means "hard to fuse". Refractories are therefore the class of materials which withstand high temperatures, resist the action of corrosive liquids and dust laden currents of hot gases that come in contact with materials (Chesti, 1994). According to American Society for Testing and Materials, ASTM (1995), refractories are inorganic materials, usually non-metallic used to withstand high temperatures. Thus, refractory materials are characterized by the ability to withstand not only heat but chemical and slag attack, abrasion impact, resist thermal shock and carry sustained structural stresses at high operating temperatures for as long as years, Sullayman, (2006). Refractories belong to the class of ceramic materials which are employed for high temperature applications, usually above $1000 \mathrm{C}$. Most refractories are made from naturally occurring high melting oxides of $\mathrm{SiO} 2, \mathrm{MgO}, \mathrm{Cr} 2 \mathrm{O} 3$, and $\mathrm{ZrO}$. Refractories are used in almost every industry in whose heat is employed such as in metallurgical, chemical, cement, glass and petrochemicals industries. They are used for the construction and maintenance of furnaces, kilns reactor, sand boilers (Jock, et al., 2013)

Refractory materials have a crucial impact on the cost and quality of steel products. The diversification of steel products and their cleanliness requirement in recent years have increased the demand for high quality refractory. Steelmaking for example requires high temperatures 1600 degree centigrade. In addition, steelmaking handles high temperature phases like molten steel, slag and hot gases. These phases are chemically reactive; thus, refractory materials are required to produce steels.

It is regrettable, that a huge amount of money, about $\$ 229$ million, is expended annually to import refractory materials into Nigeria (Apeh, 2014). Various researchers like, Hassan, (2005); Apeh et al., (2011) and Nurudeen, (2010) argue that, this huge spending could be avoided if the bricks were produced locally in Nigeria. These refractory materials play a very significant role in high temperature environment, especially, in furnace 
lining, construction and other applications. They have wide applications in ceramics and glass industries, iron and steel plants, foundries, cement factories, petrochemical industries etc., (Esezobor, Apeh, Udo, Fabiyi, Apeh, 2015).

Refractory are classified into various groups based on several factors, such as the chamicomineralogical properties, the degree of refractories, method of production, etc. All kaolin and fireclay refractories belong to the aluminosilicate group of refractories. This grouping is derived from the chemical and mineralogical constituents of the composing materials, (Sullayman, 2006).

\subsection{Importance of bricks production in Nigeria}

The refractory bricks production using manual brickmaking machine for kiln building will serve as a means to address the long-term problems of brickmaking in this country. The machine bricks will encourage the development and use of indigenous technology for the production of refractory bricks for building kiln, furnace and fireplace for industries in Nigeria. This study will also improve the production capacity of made in Nigeria bricks in commercial quantities that will in the long run help reduce the price of imported bricks. The study will also serve as instructional materials for teaching and learning ceramics kiln construction at all levels in this country. In the long run, the construction of this machine will help reduce the cost of production of refractory brick leading to conservation of foreign exchange.

\subsection{Historical background of brickmaking and types}

Fired bricks are one of the long lasting and strongest building materials, sometimes referred to as artificial stone and have been used since circa $5000 \mathrm{BC}$. Air-dried bricks, also known as mudbricks, have a history older than fired bricks, and have an additional ingredient of a mechanical binder such as straw.

The earliest bricks were dried brick, that were formed from clay bearing earth or mud and dried usually in the sun until they were strong enough for use. The oldest discovered bricks, originally made from shaped mud and dating before $7500 \mathrm{BC}$, were found at Tell Aswad, in the upper Tigris region (Iran) and in southeast Anatolia close to Diyarbakir, (Harbison, 1992). More recent findings, dating between 7,000 and 6,395 BC, come from Jericho, CatalHüyük and the ancient Egyptian. Firedbrick was used as early as 3000 BC in early Indus Valley Cities, (Kenoyer, 2005).

In pre-modern China, bricks have been used since the 2 nd millennium BC at a site near Xi'an. Bricks were produced on a larger scale under the Western Zhou dynasty about 3,000 years ago, and evidence for some of the first fired bricks ever produced has been discovered in ruins dating back to the Zhou dynasty.

The transition from the traditional method of production known as hand moulding to a mechanized form of mass production slowly took place during the first half of the nineteenth century. A few rudimentary tools came to help in streamling production. In 1830, Nathaniel Adams of Newburgh and Cornwall, New York invented a moulding machine which required human or animal labour (Ewan, 1970).

Another brickmaking machine that was patented by Henry Clayton, employed at the Atlas Works in Middlesex, England, in 1855, and was capable of producing up to 25,000 bricks daily with minimal supervision. Based on similar concepts a machine has been developed after considering the circumstances of rural setup in African regions. The machine is a batch type production facility and is capable of producing three bricks in one batch. The capacity of the machine is 500 bricks per shift, Soraj, (2011). In 1874, another brickmaking machine invented to automatically dust the mould with sand, so that it could keep up with the Vervalenmoulding machine. Yet, another brickmaking machine was patented by Cyrus Chambers of Philadelphia, that was able to use stiff mud forced out in long ribbons on a conveyor belt, transferred to mould and cut by revolving cutter (Ewan, 1990). Brick improvements have continued into the twentieth century. Such improvements include rendering brick shape absolutely uniform, lessening weight, and speeding up the firing process. For example, modern bricks are seldom solid. Some are pressed into shape, which leaves a frog, or depression, on their top. Others are extruded with holes that will later expedite the firing process by exposing a larger amount of surface area to heat. Both techniques lessen weight without reducing strength, (Millberg, 2010). However, Kolade, in 2016 design and developed insulating compaction brickmaking machine, operated manually and produced one brick at a time. Example of high-tech machines presently available are the Light Manual Brick Press known as CINVA RAM and the Montgomery's dynamics Compressed Earth Brick (CEB) making machine. They cost between $\mathrm{N} 1,200,000$ and N1,800,000 as at 2015, (Yakubu and Umar, 2015).

\subsection{Potters kiln bricks or firebricks}

Brick can be defined as a small rectangular block of clay backed in the sun or in the kiln (an enclosed chamber in which heat is produce to fire, burn or dry materials), which used as building material, Karnopp et al. (1999). Brick is also defined as a smaller unit either solid or with small cores usually made of clay. The fired solid brick material density is approximately $1900 \mathrm{~kg} / \mathrm{m} 3$ while the perforated brick is between $1400-1500 \mathrm{~kg} / \mathrm{m} 3$, (Steven, 2017). They are sometimes referred to as masonry units (MU). The decision as to which method to use or brick 
to make or employed depends on several factors: such as the raw materials available, characteristics of the raw material and production costs, compressibility factors such as strength, water resistance, the existing facilities for maintenance of production tools and machines, the needed productivity etc. (Lennart and Whitaker, 1988). According to Rosacometta (1997), There are three basic types of brick which are unfired, fired, and chemically set bricks. Each type is manufactured differently. Fired bricks are fired in a kiln which makes them durable. Modern fired clay bricks are formed in one of three processes soft mud, dry press, or extruded. Depending on the country, either the extruded or soft mud method is the most common, since they are the most economical. Normally, bricks contain the following ingredients: -

- $\quad$ Silica (sand) $-50 \%$ to $60 \%$ by weight

- Alumina- $20 \%$ to $30 \%$ by weight

- Lime -2 to $5 \%$ by weight

- Iron oxide $-\leq 7 \%$ by weight

- Magnesia - less than $1 \%$ by weight

\subsection{Batching and mixing of refractory material}

Batching is the process of measuring various quantities of materials or components. This can be done by mass or by volume. Out of the two, batching by mass is professionally preferable as it eliminates errors due to the variation contained in a specific volume. However, most producers, especially those that batch manually, use the volume batching process because it is simpler and much more convenient than weight batching. It is the same manual technique also applied in this research. Manual batching is done using head pans, wheel barrow or specially constructed wooden gauge boxes, (Kolawole, 2017).

\subsection{Compaction}

A compaction pressure equivalent to $15.45 \mathrm{MPa} \mathrm{cm} 2$ (one imperial tone per square inch) is applied to normal refractory brick (Sullayman, 2006). Compaction is achieved by mechanical vibrator or by manual (hand) compaction. In this study manual compaction was adopted in order to improve from the local soft mud or local brick production to manual machine brickmaking process.

\subsection{Materials for brick production}

Although kaolin clay is the major and most valued material for refractory brickmaking but, there are as many as different types of materials and methods for firebricks. And for the purpose of this research Kaolin and Sawdust were used as follows: -

- Value of clay

Clay is one of the oldest building materials on Earth. Between one half and two thirds of the world's population, in both traditional societies as well as developed countries, still live or work in buildings made with clay, often baked into brick, due to load bearing quantities. As a primary ingredient in many natural building projects, clay is used to plaster structures and building elements such as floors and clay paints and ceramic building material. Clay was used traditionally as medicine to soothe an upset stomach. Also, some animals such as parrots and pigs ingest clay for similar reasons.

- Kaolin Clay

According to Sullayman, 2006, clay is earthy material that is plastic when moist but hard when fired. It is composed mainly of fine particles of hydrous aluminum silicates and other minerals that is used for brick, tile, and pottery. Geologic clay deposits are mostly composed of phyllosilicate minerals containing variable amount of water trapped in the mineral structure. Clays are plastic due to particle size as well as water content, and become hard, brittle and non-plastic upon drying or firing. Depending on the soil's content where it is found, clay can appear in various colours from white to dull grey or brown to deep orange red.

- Kaolinite is a clay mineral, part of the group of industrial minerals, with the chemical composition $\mathrm{Al}_{2} \mathrm{Si}_{2} \mathrm{O}_{5}(\mathrm{OH})_{4}$. It is a layered silicate mineral, with one tetrahedral sheet of silica linked through oxygen atoms to one octahedral sheet of alumina octahedra. Kaolin, also called china clay, soft white clay that is an essential ingredient in the manufacture of china and porcelain and is widely used in the making of paper, rubber, paint, and many other products. Kaolin is named after the hill in China (Kao-ling) from which it was first discovered for centuries. Among the many uses for this mineral are the paper industry, medications, skincare products, porcelain, and cosmetics. Sources of it can be found all over the world, including Nigeria.

- Sawdust

Sawdust or wood dust is a by-product or waste product of woodworking operations such as sawing, milling, planning, routing, drilling and sanding. It is composed of fine particles of wood. These operations can be performed by woodworking machinery, portable power tools or by use of hand tools. Sawdust is the main component of particleboard. Wood dust is a form of particulate matter, or particulates. 
- Minerals

Several materials can be incorporated into the brick making process. The commonly added minerals include calcium, magnesium and phosphorus; as well as potassium, chloride and sulfur. Trace minerals include iron, copper, zinc, manganese, fluoride, selenium and cobalt. During firing process these minerals melt to form the brick more quickly, leaving a glassy coat on the brick, and also contribute to hardening process, (Kolade, 2016).

- Batch Mixing

After coupling the machine, it was subjected to test to produce bricks in order to observe its performance. There are two main stages in the production of insulating bricks; namely material preparation and the making of the brick. Kaolin, fireclay and combustibles materials were used for the composition of the insulating firebricks. The raw materials required for the production of insulation bricks could be categorized into three namely: aggregates, binders and combustibles or pore formers.

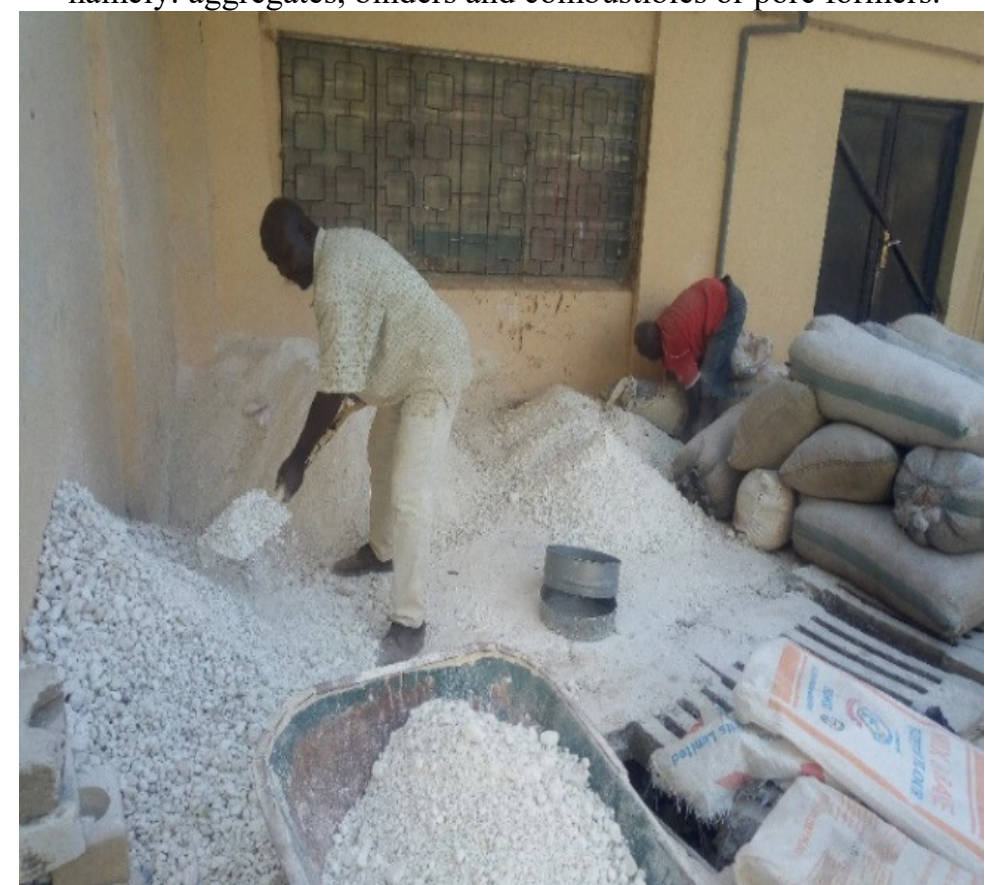

Plate $i$ : Sieving and mixing the brick materials,

Source: Research Photograph, Garba (2018)

The insulating firebricks were made of a mixture of (kaolin) and sawdust. The sawdust burnt off in the process of firing in the kiln, thereby leaving plenty of holes in the insulating bricks. These pores or holes make the insulating bricks better insulator when they are used in kiln building because heat cannot pass through motionless air which is trapped in the holes.

The kaolin used was acquired from Kankara in Katina State and saw dust from Zaria, Kaduna State were measured in percentages for the batches to see the best body formulation that will go along with the machine in the course of insulating fire brick production. These compositions are not so different from the commonly used ones for good insulating bricks. The bodies were measured in $\mathrm{kg}$ to determine the ratio of composition. Below is the table for the batches.

\section{Chemical Analysis of Kankara}

Kankara clay have their elements constituent expressed as follows: 
Table 1. The Results of the chemical analysis on Kankara clay clay.

\begin{tabular}{ll}
\hline Element & Kankara Kaolin \\
$\mathrm{SiO} 2$ & 54.80 \\
$\mathrm{~A} 103$ & 31.60 \\
$\mathrm{Na} 2 \mathrm{O}$ & - \\
$\mathrm{K} 2 \mathrm{O}$ & 0.88 \\
$\mathrm{CaO}$ & 0.409 \\
$\mathrm{MgO}$ & 1.002 \\
$\mathrm{TiO} 2$ & 3.13 \\
$\mathrm{Cr} 2 \mathrm{O} 3$ & 0.073 \\
$\mathrm{~V} 2 \mathrm{O} 5$ & 0.09 \\
$\mathrm{MnO}$ & 0.15 \\
$\mathrm{Fe} 2 \mathrm{O} 3$ & 0.87 \\
$\mathrm{CuO}$ & 0.016 \\
$\mathrm{Ga} 2 \mathrm{O} 3$ & - \\
$\mathrm{ZnO}$ & - \\
$\mathrm{Y} 2 \mathrm{O} 3$ & - \\
$\mathrm{I}$ & - \\
$\mathrm{PbO}$ & - \\
$\mathrm{NiO}$ & - \\
$\mathrm{PbO}$ & - \\
$\mathrm{NiO}$ & - \\
$\mathrm{SrO}$ & - \\
$\mathrm{L} . \mathrm{O} . \mathrm{I}$. & 11.09 \\
$\mathrm{TiO} 2$ & 0.27 \\
$\mathrm{BaO}$ & 0.024 \\
\hline
\end{tabular}

Source: National Geosciences Research Laboratory, (NGRL), Kaduna (2018)

The result shows that Kankara clay contains two major oxides, Si02-54.80 wt \%, A1203-3 1.60 wt \% and other minor constituent elements as shown below; the result clasifie this clay as kaolin,

\subsection{Methods of production adopted}

There are three main methods used for shaping the brick includes Moulded bricks, Dry pressed bricks and Extruder bricks. But, for the purpose of this study extruder bricks method was adopted.

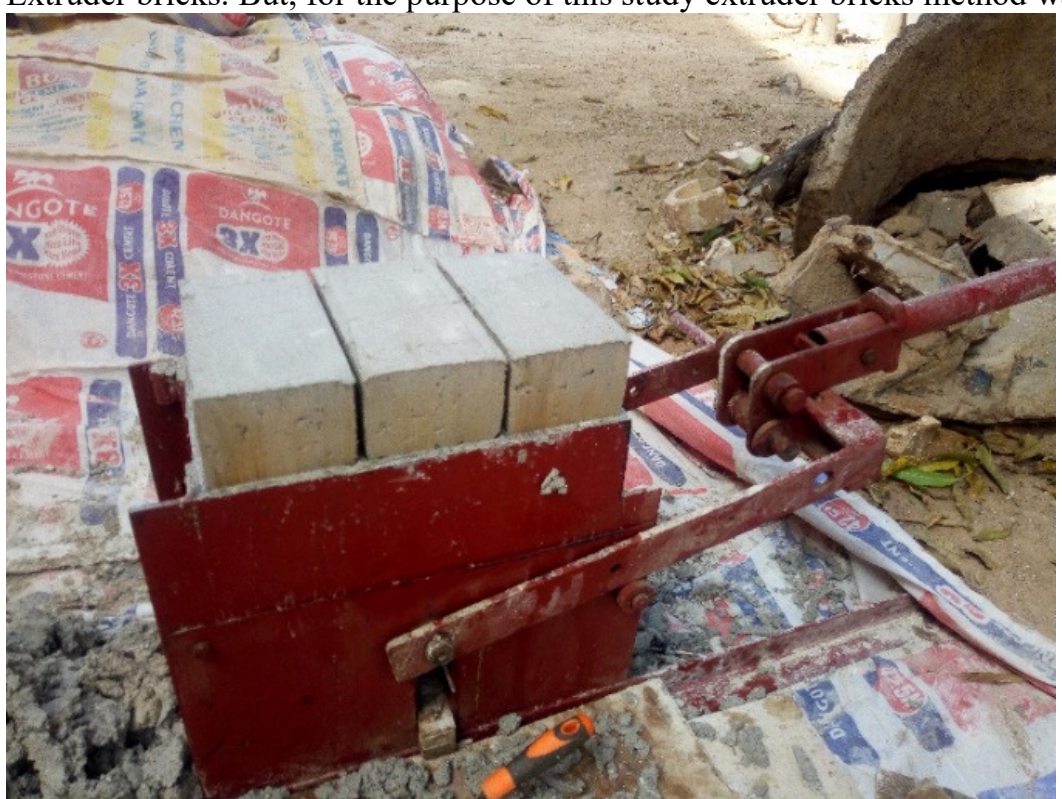

Plate ii: Manual Brickmaking Machine, Kolade (2014),

Source: Research Photograph, Garba (2018)

\subsection{Extruded bricks}

The clay for the extruded bricks is mixed with $10-15 \%$ water (stiff extrusion) or 20 to $25 \%$ water (soft extrusion) 
in a pug mill. This mixture is forced through a die to create a long cable of material of the desired width and depth. This mass is then cut into bricks of the desired length with a cutting wire. Most structural bricks are made by this method as it produces hard, dense bricks. Suitable dies can produce perforations as well.

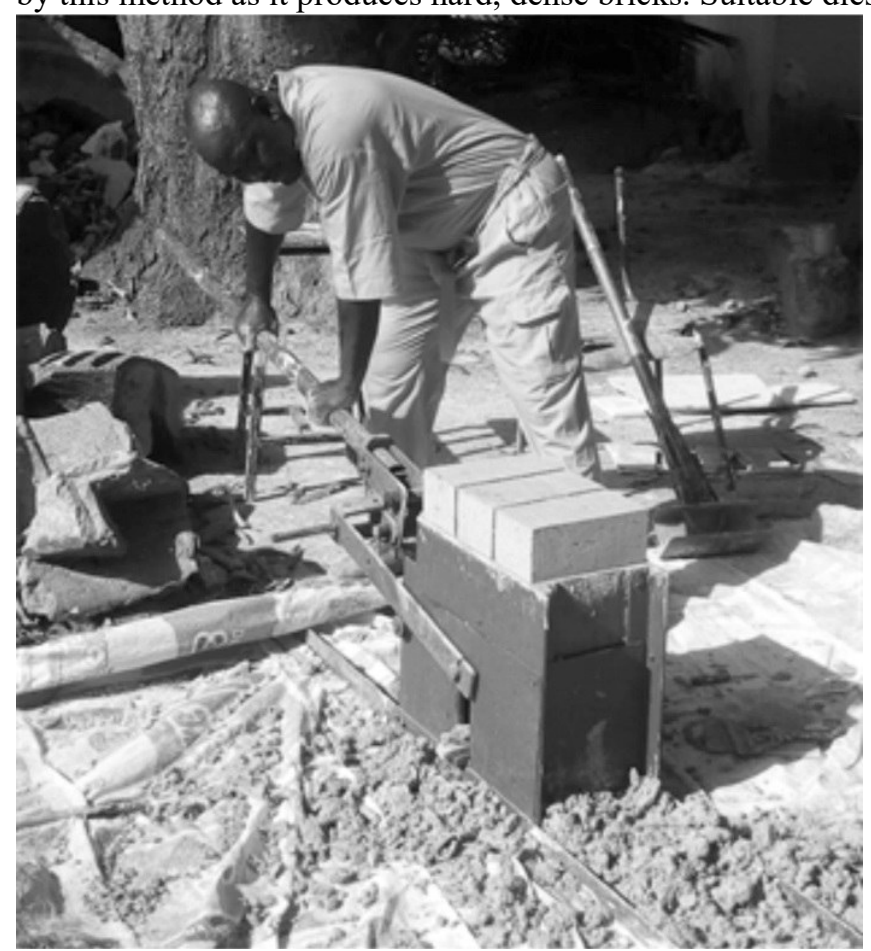

Plate iii: The Bricks Extruded out from the machine,

Source: Research Photograph (2018)

\subsection{Process description}

Brick production involves clay mining, grinding, screening and blending of raw materials. It also includes forming, cutting, or shaping, drying, firing, cooling, and storage of the final products.

The method adopted in this research work is experimental research. Research design is a plain, structure and strategy of investigating conceived information so as to obtain viewers to research questions and to control variance Kerlinger, (1977).

The materials, procedures, thermal and mechanical test of the refractory bricks produced by the machine which leads to the success of this research work are described in this chapter. The researcher who developed the manual brickmaking machine which were used for this study was Kolade, (2016).

Who design and developed insulating brickmaking machine, operating manual compaction and producing one brick at a time manually, as a master's degree research at Ahmadu Bello University, Zaria, Industrial Design Department.

The manual brick machine is a hand pressed moulding type. The clay is mixed with minimal amount of water of 10 percent and the well mixed clay will be filled into the mould. The top cover will be locked to prevent the clay from being forced out of the mould. After the filling the handle which serves as dual purposes such as compression and ejection will be pulled with force to compress the clay that was filled into the mould then the brick is formed. After the compression the top cover will be opened, then the handle is pressed again to the other way for the brick to come up and the brick will be removed to a safe place for drying. The action will be repeated until the desire numbers of bricks are obtained.

\subsection{Drying and kiln firing}

The bricks will be placed and dried gradually in an open shade in order to minimize the rate of shrinkage. After the bricks are well dried, it will be arranged or loaded in the kiln where it will be fired to $1280^{\circ} \mathrm{C}$ and above, depending on the refractory product requirement. 


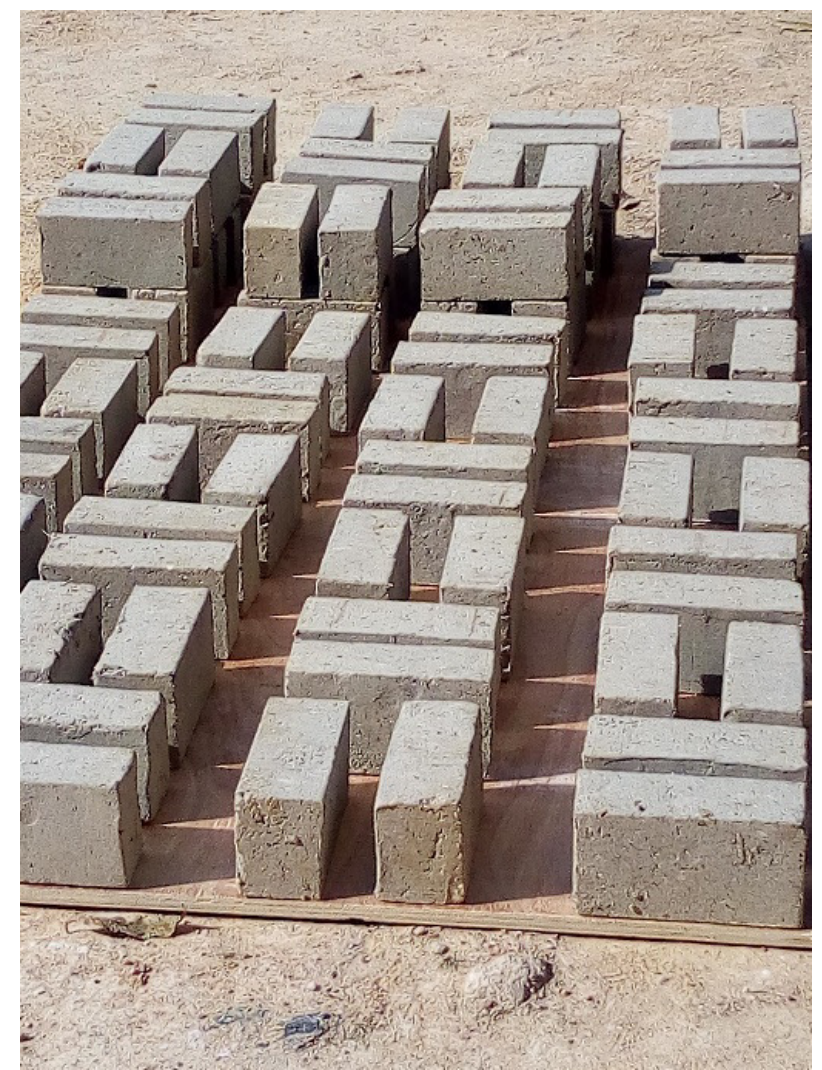

Plate iv: Open Drying of the Bricks,

Source: Research Photograph

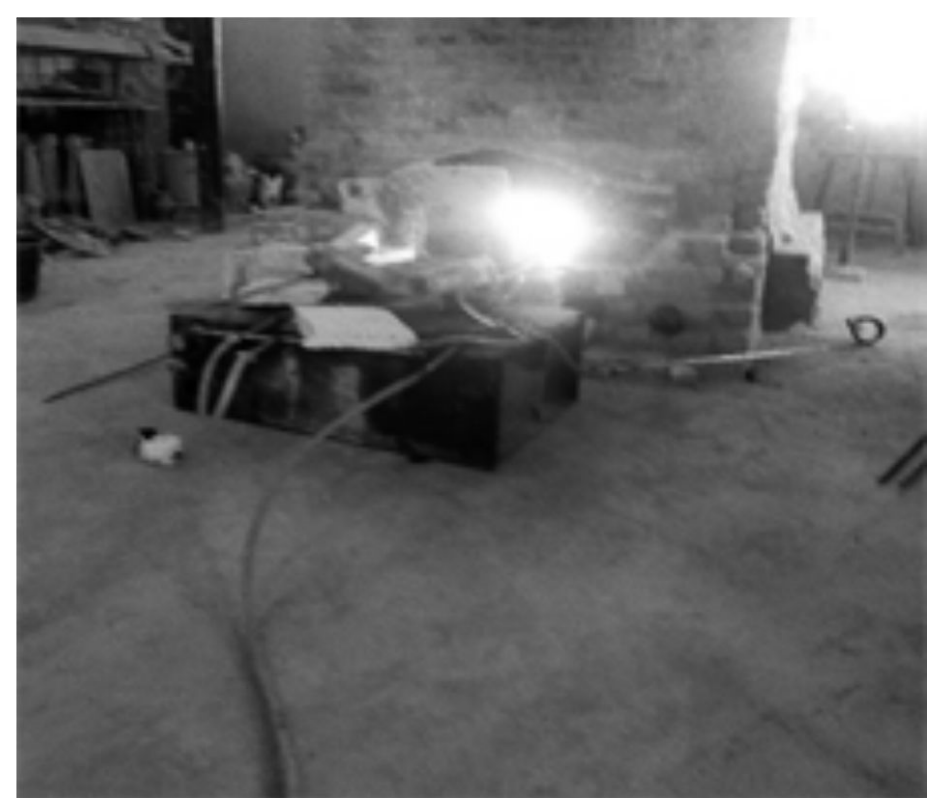

Plate v: Firing of the Bricks in a Kiln,

Source: Research Photograph 
4.1 Results and discussions

Table 2. Insulating Refractory Bricks Production flow

Insulating Refractory Bricks Production flow

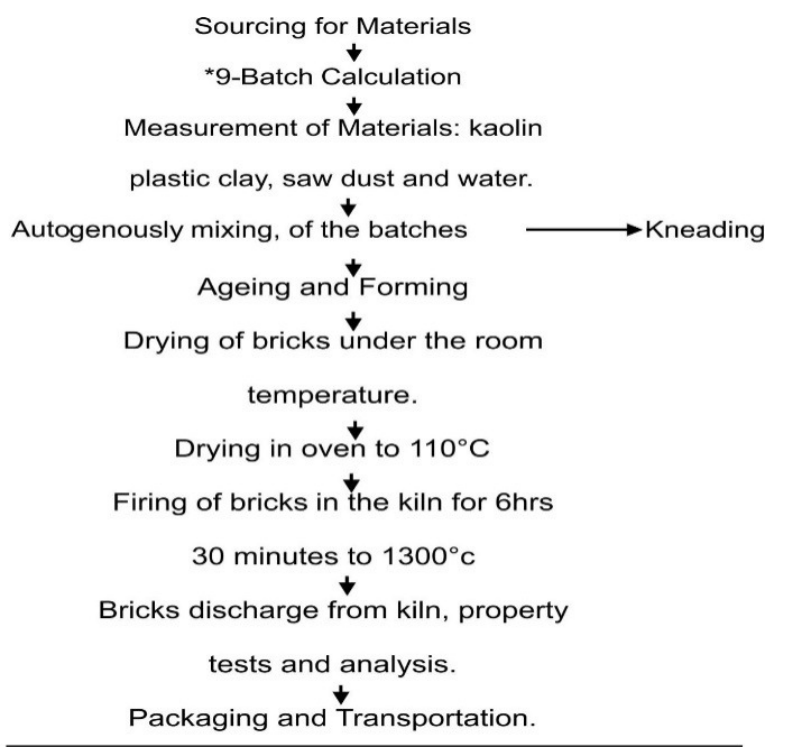

The diagram below shows the batch formulation adopted in the research: -

Table 3. Batch formulation for the Production of the Brick.

\begin{tabular}{|c|c|c|c|c|c|c|c|}
\hline Materials & $\begin{array}{l}\text { Kaolin \% } \\
\text { in volume }\end{array}$ & $\begin{array}{l}\text { Ball Clay } \% \text { in } \\
\text { volume }\end{array}$ & $\begin{array}{l}\text { Saw dust \% in } \\
\text { volume }\end{array}$ & $\begin{array}{l}\text { Dry } \\
\text { (kg) }\end{array}$ & weight & $\begin{array}{l}\text { Wet } \\
(\mathrm{kg})\end{array}$ & Weight \\
\hline Batch 1 & $\begin{array}{c}\text { Calcined Kaolin } \\
50\end{array}$ & 20 & 30 & & 8.5 & & 10 \\
\hline Batch 2 & 50 & 20 & 30 & & 8.5 & & 10 \\
\hline Batch 3 & 50 & 20 & 40 & & 7 & & 10 \\
\hline Batch 4 & 50 & $10-* 9$ & 50 & & 6.5 & & 9.8 \\
\hline Batch 5 & 50 & 20 & 50 & & 6 & & 8.7 \\
\hline Batch 6 & 50 & Nil & 50 & & 5.75 & & 9.4 \\
\hline
\end{tabular}

Source: Laboratory and Studio Analysis (2018)

The batches were measured on scale differently on the floor. Both the clay and saw dust were screened to remove foreign bodies that may be present before mixing together the different batches.

Hand trowel was used for mixing the compositions, and it was done thoroughly before mixing with water. Six-line blends were made. The required amount of raw material was properly weighed and dry mixed for some period of time. Until a consistency state was reached which looks like paste water was gradually added to the compositions one after the other and mixed properly. The consistency of the mixture was checked with hand filling method to know the amount of water requirement for each of cut batches.

Several tests were conducted to ascertain the potential and the capability of the brick making machine for the production of brick as good refractory materials. The test for suitability of the bricks produced were also done by putting the bricks through several tests, including physical and chemical tests, to be very sure that the bricks can be referred to as being refractory. Among these tests were thermal conductivity which is attributed to the exchange of energy between adjacent molecules and electrons in the conducting medium. And is a branch of materials science where the properties of materials are studied as they change with temperature. Several methods are commonly used these are distinguished from one another by the property which is measured. Some these properties include liner shrinkage, apparent porosity, bulk density, cold crushing strength, thermal shock resistance, and refractory under load (RUL), (Sullayman 2006). However, the mechanical properties of a material are those properties that involve a reaction to an applied load. The mechanical properties of metals determine the range of usefulness of a material and establish the service life that can be expected.

\subsection{Press Forming of Bricks}

Insulating bricks of a standard size of $230 \mathrm{~mm} \times 115 \mathrm{~mm} \times 76 \mathrm{~mm}$ were successfully made using the compression and ejection method. Refractory aggregates weighing 3,6kg per brick was found to be ideal for making the standard brick size of $230 \mathrm{~mm}$ x 115 x $64 \mathrm{~mm}$ (i.e. 9" x 4.5 " x 3") size of brick.

Charges or feeding into the mould that were less than $3.6 \mathrm{~kg}$ produced bricks that were shorter than $76.2 \mathrm{~mm}$ (or 
3inches) high, the reverse was the case when charges were more than $3.6 \mathrm{~kg}$.

- Brick Discharge/Removal from Mould

Sufficient lubrication of the internal surfaces of the moulds with used engine oil made the brick easy to remove without any major injury.

- Drying of Bricks

The bricks, after drying for 14 days in an exposed form under room temperature were visibly observed to be dried. As a result of this the bricks became more fragile due to a substantial loss in water of plasticity. Flaking of the bricks especially at the sharp edges became apparent in handling of them.

\subsection{Physical Properties of Brick samples}

Table 4.5 shows the physical properties of the brick samples shock as the states of each brick samples like colour, hardness, structure and efflorescence.

Table 4. The Physical Properties of Brick samples

\begin{tabular}{|c|c|c|c|c|c|}
\hline Batch No & After Firing & Colour Change & Sound Test & \multicolumn{2}{|c|}{ StructureEfflorescence } \\
\hline $\begin{array}{l}\text { Line Blend } 1 \\
\text { Soluble Salts }\end{array}$ & No crack & Creamy & Ringing Sound & Homogenous & No \\
\hline $\begin{array}{l}\text { Line Blend } 2 \\
\text { Soluble Salts }\end{array}$ & No crack & White & Ringing Sound & Homogenous & No \\
\hline $\begin{array}{l}\text { Line Blend } 3 \\
\text { Soluble Salts }\end{array}$ & No crack & Creamy & Ringing Sound & Homogenous & No \\
\hline $\begin{array}{l}\text { Line Blend } 4 \\
\text { Soluble Salts }\end{array}$ & No crack & Creamy & Ringing Sound & Homogenous & No \\
\hline $\begin{array}{l}\text { Line Blend } 5 \\
\text { Soluble Salts }\end{array}$ & No crack & Creamy & Ringing Sound & Homogenous & No \\
\hline Line Blend 6 & No crack & Creamy & Ringing Sound & Homogenous & No \\
\hline
\end{tabular}

Soluble Salts

Source: Laboratory and Studio Analysis (2018)

- Crack

In observing the bricks from sample 1-6 there was no crack and also no lamination. Sample 1-6 are regular in shape and size, smooth and with even sides. The corner of the samples were all in angle $90^{\circ} \mathrm{c}$ degrees. The absolute lack of visible cracks in all the fired samples is due to its relatively higher level of silica content and feldspar. The feldspars are to serve as flux.

- Colour

Sample 6 the line blend that was not mixed with ball clay fired to white which shows that there is no or very minute presence of iron oxide. Colour bearing impurities, especially iron oxide the absence of this in this sample accounts for the whiteness of the brick after being subjected to firing. This suggests high refractoriness of the blend. Sample 1-5 has colour variations as per the presence of ball clay in percentage.

- Sound Test

Samples 1-6 produced very good and strong sounds when held within finger tips and lightly hit one against the other and this shows that the bricks are good for refractories.

- Hardness test

Samples 2,3,4,5,6, except sample I when the surface were scratched with finger nail there was no impression left on the surface, but sample 1 which was made with calcined clay is having crumple like structure though not so serious but still suitable as a refractory brick.

- $\quad$ Structure Test

They were all homogeneous in structure, pores present, compact, and free from defects for example lumps. This means that both clays bond very well during mixing.

- Efflorescence Test

There was none of the sample bricks that have imperceptible efflorescence.

\subsection{Properties of the Insulating Bricks}

Properties test were conducted on the insulating bricks products made. The properties examined include Modulus of Rupture (MOR) to establish their bending strength, bulk density and apparent porosity. The results obtained for the different experiments carried out in this investigation are presented in tables and the properties are discussed below.

Sinterability of the Brick Samples

Dry shrinkage and firing shrinkage of the sample bricks were also investigated by this study and documented in Table 4.3 below. Linear shrinkage in dried and fired bricks was also indicated in the table below. 
Table 5. Shrinkage Values

\begin{tabular}{|c|c|c|c|c|c|c|}
\hline $\begin{array}{l}\text { Sample } \\
\text { (code) }\end{array}$ & $\begin{array}{l}\text { Original } \\
\text { Temp. } \\
\text { Length } \\
\text { (ram) }\end{array}$ & $\begin{array}{l}\text { Dry } \\
\text { Length } \\
(\mathrm{mm})\end{array}$ & $\begin{array}{l}\text { Length } \\
(\mathrm{mm})\end{array}$ & $\begin{array}{l}\text { Dry } \\
\text { Shrinkage } \\
\%\end{array}$ & $\begin{array}{l}\text { Fired } \\
\text { Shrinkage } \\
\%\end{array}$ & $\begin{array}{l}\text { Total } \\
\text { Shrinkage } \\
\%\end{array}$ \\
\hline 1 & $\begin{array}{l}230 \\
1300\end{array}$ & 227 & 215 & 1.30 & 5.28 & 6.52 \\
\hline 2 & $\begin{array}{l}230 \\
1300\end{array}$ & 220 & 211- & 4.34 & 4.09 & 8.26 \\
\hline 3 & $\begin{array}{l}230 \\
1300\end{array}$ & 222 & 210 & 3.47 & 5.40 & 8.69 \\
\hline 4 & $\begin{array}{l}230 \\
1300\end{array}$ & 222 & 215 & 3.47 & 3.15 & 6.52 \\
\hline 5 & $\begin{array}{l}230 \\
1300\end{array}$ & 227 & 213 & 1.30 & 6.16 & 7.39 \\
\hline 6 & 230 & 223 & 215 & 3.04 & 3.58 & 6.52 \\
\hline
\end{tabular}

Sample, Original Dry, Fired Dry, Fired, Total Temp.

\subsection{Bulk Density and Apparent Porosity}

The values obtained from the set-up for bulk density and apparent porosity were recorded. These values were later used for calculation, using the equation to obtain the actual bulk density and apparent porosity of the brick samples.

Table 6. Percentage of Apparent Porosity, Water Absorption, Apparent Density and Bulk Density.

\begin{tabular}{llllllll}
\hline $\begin{array}{l}\text { Sample } \\
\text { Code }\end{array}$ & $\begin{array}{l}\text { Fired } \\
\text { weight } \\
\text { Density } \\
(\mathrm{g})\end{array}$ & $\begin{array}{l}\text { Suspended } \\
\text { weight }\end{array}$ & $\begin{array}{l}\text { Soaked } \\
\text { weight }\end{array}$ & $\begin{array}{l}\% \\
\text { Apparent }\end{array}$ & $\begin{array}{l}\text { \% Water } \\
\text { Absorption }\end{array}$ & $\begin{array}{l}\text { Apparent } \\
\text { Density }\end{array}$ & Bulk \\
& $(\mathrm{g} / \mathrm{cm} 3)$ & & $(\mathrm{g})$ & Porosity & & & \\
$(\mathrm{g} / \mathrm{cm} 3)$ & \\
\hline 1 & 1934 & 1602 & 204 & 79.7 & 65.66 & 5.82 & 1.20 \\
2 & 1962 & 1483 & 2966 & 67.70 & 51.17 & 4.01 & 1.32 \\
3 & 2463 & 1.741 & 3483 & 58.57 & 41.41 & 3.41 & 1.41 \\
4 & 1961 & 1500 & 3000 & 69.26 & 52.98 & 4.25 & 1.30 \\
5 & 2182 & 1566 & 3132 & 60.60 & 43.47 & 3.53 & 1.37 \\
6 & 1745 & 1615 & 3230 & 91.95 & 85.10 & 13.4 & 1.08 \\
\hline
\end{tabular}

Source: Laboratory Source: Laboratory and Studio Analysis

Table 7. Percentage of Moisture content, Wet Weight Dried Weight Shrinkage of Samples.

\begin{tabular}{llll}
\hline Batch Code & Wet Weight $(\mathrm{g})$ & $\begin{array}{l}\text { Dry Weight } \\
(\mathrm{fe})\end{array}$ & \% Moisture Content \\
\hline 1. & 360 & 280 & 22.22 \\
2. & 410 & 32.5 & 21.95 \\
3. & 430 & 310 & 27.91 \\
4. & 410 & 290 & 29.27 \\
5. & 410 & 300 & 26.83 \\
6. & 380 & 290 & 23.68 \\
\hline
\end{tabular}

Source: Laboratory Source: Laboratory and Studio Analysis

\subsection{Modulus of Rupture}

The main purpose of this investigation was to determine the bending strength of the brick samples. The values obtained showed a significant difference in the samples. All the six samples of the bricks showed these results and only break at the following points. 
Table 8. Values of Modulus of Rupture

\begin{tabular}{|c|c|c|c|c|c|}
\hline Test & $\begin{array}{l}\text { Breaking } \\
\text { Firing }\end{array}$ & Length & Width & Thickness & Modulus \\
\hline Specimen & $\begin{array}{l}\text { Load (kN) } \\
\text { Temp. oC }\end{array}$ & Distance Between & $\mathrm{mm}$ & $\mathrm{mm}$ & of rupture \\
\hline Code & & Support (mm) & & & $\mathrm{kgf} / \mathrm{cm} 2$ \\
\hline 1. & $\begin{array}{l}5.0 \\
1300^{\circ} \mathrm{c}\end{array}$ & 210 & 00 & 85 & 2.18 \\
\hline 2. & $\begin{array}{l}13.3 \\
1300^{\circ} \mathrm{C}\end{array}$ & 210 & 00 & 85 & 5.80 \\
\hline 3. & $\begin{array}{l}19.4 \\
1300^{\circ} \mathrm{C}\end{array}$ & 210 & 05 & 85 & 1.32 \\
\hline 4. & $\begin{array}{l}22.7 \\
1300^{\circ} \mathrm{c}\end{array}$ & 213 & 3 & 75 & 1.25 \\
\hline 5. & $\begin{array}{l}24.0 \\
1300^{\circ} \mathrm{c}\end{array}$ & 212 & 5 & 75 & 1.32 \\
\hline 6. & 9.5 & 215 & 0 & 80 & 2.20 \\
\hline
\end{tabular}

$1300^{\circ} \mathrm{c}$

Source: Laboratory and Studio Analysis

Table 9. Summary of the Tests, Moisture Content, Modulus of Rupture, Apparent Porosity

\begin{tabular}{|c|c|l|l|l|c|c|c|}
\hline $\begin{array}{l}\text { Samples } \\
\text { Lines } \\
\text { Blend }\end{array}$ & $\begin{array}{l}\text { Total } \\
\text { Shrinkage } \\
(\mathbf{\%})\end{array}$ & $\begin{array}{l}\text { Moisture } \\
\text { Content } \\
(\mathbf{\%})\end{array}$ & $\begin{array}{l}\text { Modulus of } \\
\text { rupture } \\
\left(\mathbf{k g f} / \mathbf{c m}^{2}\right)\end{array}$ & $\begin{array}{l}\text { Apparent } \\
\text { porosity }\end{array}$ & $\begin{array}{l}\text { Wo Water } \\
\text { absorption }\end{array}$ & $\begin{array}{l}\text { apparent } \\
\text { Density } \\
\left(\mathbf{g} / \mathbf{c m}^{\mathbf{3}}\right)\end{array}$ & $\begin{array}{l}\text { Bulk } \\
\text { Density } \\
\left(\mathbf{g} / \mathbf{c m}^{\mathbf{3}}\right)\end{array}$ \\
\hline 1. & 6.52 & 22.22 & 2.18 & 79.27 & 65.66 & 5.825 & 1.207 \\
\hline 2. & 8.26 & 21.95 & 5.80 & 67.70 & 51.17 & 4.012 & 1.322 \\
\hline 3. & 8.69 & 27.91 & 1.32 & 58.57 & 41.41 & 3.413 & 1.414 \\
\hline 4. & 6.52 & 29.27 & 1.25 & 69.26 & 52.98 & 4.253 & 1.307 \\
\hline 5. & 7.37 & 26.83 & 1.32 & 60.60 & 43.47 & 3.538 & 1.373 \\
\hline 6. & 6.97 & 23.68 & 2.20 & 91.95 & 85.10 & 13.42 & 1.080 \\
\hline
\end{tabular}

Source: Laboratory and Studio Analysis

Table 10. Thermal Shock Test

\begin{tabular}{lcccccc}
\hline Blend & Sample 1 & Sample 2 & Sample 3 & Sample 4 & Sample 5 & Sample 6 \\
\hline Temp. & $1300^{\circ} \mathrm{C}$ & $1300^{\circ} \mathrm{C}$ & $1300^{\circ} \mathrm{C}$ & $1300^{\circ} \mathrm{C}$ & $1300^{\circ} \mathrm{C}$ & $1300^{\circ} \mathrm{C}$ \\
No of Cycle & 30 & 30 & 30 & 30 & 25 & 30 \\
\hline
\end{tabular}

Source: Laboratory and Studio Analysis (2018).

\subsection{Summary and Conclusion}

The aim of this study is to improve the quality of refractory bricks production using manual brickmaking machine at compaction pressure of about 300 pound-force per square inch (p.s.i) (2 MPa). This is equivalent to ASTM D1633-00 stabilization standard for kiln building in order to solved some of the problems facing kiln construction. Sourcing for the brick raw materials (kaolin clay and saw dust), as well as conducting thermal and mechanical tests on the refractory bricks produced with the machine are also the consideration of this research. Considerable effort was made in sourcing for the right material, measurement, formulation of different batches, mixing and making the line blend, making the bricks, then drying and firing in order to meet a required standard. The bricks produced by the machine were subjected to firing at the temperature of about $1300^{\circ} \mathrm{C}$ and after firing they were taken for tests, such as porosity, bulk density and modulus of rupture. The brick produced on the basis of the analysis of the data for this study, the insulating bricks are suitable for constructing kiln which are capable 
of being fired to temperature of $1300^{\circ} \mathrm{C}$ (to enable high temperature storage).

The refractory bricks production using manual brickmaking machine for kiln building will serve as a means to address the long-term problems of brickmaking in this country. The machine bricks will encourage the development and use of indigenous technology for the production of refractory bricks for building kiln, furnace and fireplace for industries in Nigeria. This study will also improve the production capacity of made in Nigeria bricks in commercial quantities that will in the long run help reduce the price of imported bricks. In the long run, the refractory bricks production using manual brickmaking machine for kiln building will help reduce the cost of production of refractory brick leading to conservation of foreign exchange.

\subsection{Recommendation}

- The method adopted in this study involves the use of pre-experimental procedures and this brings it to a state of lower validity and therefore sets the stage for further research. Further study should be carried out by making the brick machine to be powered electrically in order to reduce the stress associated with the manual operation.

- The study will serve as instructional materials for teaching and learning ceramics refractory brickmaking for kiln construction at all levels in this country.

- Unemployed youth willing to take ceramics as a career or means of livelihood could be engaged in learning processes involved in this study

\section{References}

Apeh, F.I. (2014). Enhancement of Refractory Characterization of Selected Nigerian Fire-Clay for furnancelinings, Doctoral Thesis at the Department of Metallurgical and Material Engineering. University of Lagos Nigeria

ASTM International (1975). Annual Books of ASTM Standards Part 17, Refractories, Glass and Ceramics Materials, Manufactured Carbon and Gr Graphite Products American Society for Testing and Materials. Philadelphia.

Chesti, A. S., (2004). Refractories: Manufacture, Properties and Applications. Prentice-Hall of India Private Limited, New Dheli, India. 55-57

Ewan, N.R., (1970). "Early Bricks Making in the Colonies". http//www.Wesjeseyhistory.org/articles/brickmaking. Restrieved12/12/2011

Esezobor, D.E., Apeh, F.I., Udo, OM.O., Fabiyi, M. and Apeh, E.S. (2015). Evaluation of Cost Effectiveness of Onibode Fire-Clay for Production of High-Quality Refractory Bricks. Journal of Materials and Characterization and Engineering, Retrieved from http://www.sirp.org/journal/jmmce. April 11, 2016

Gupta O.P., (2017). LECTURE 9 Refractory Materials, (Key words: Refractory, steelmaking, furnaces, Fuels, Furnace and refractory). http://nptel.ac.in/courses/113104059/lecture. pdf/Lecture\%209.pdf

Harbison. W., (1992). Modern Refractory Practice, Fifth Edition (Harbison-Walker Refractories: Pittsburgh, Pennsylvania, 1992), Page CR-2

Hassan, S.B. (2005). Effects of Silicon Carbide on Some Refractory Properties of Kankara Clay. Journal of Applied Science, Engineering and Technology, 5, 21-22.

Heller, B. K. and Bullock, A. M. (2001). Refractory Manufacturing NESHAP: Industry Profile, Methodology, and Economic Impact Analysis, Draft Report, EPA Contrast Number 68-D-99-024, RTI Project Number 7647.002.138. P2.

Jock, A.A., F.A., Jongs, L.S., and Kangpe, N.S. (2013). Development of Refractory Bricks from Nigeria Nafuta Clay Deposit, International Journal of Materials, Methods and Technologist, Vol. 1, No. 10, pp: 189-195. Restricted from http//ilmmt.com. April 10, 2016.

Karnopp, D.C, Margolis, D. L,. and Rosenberg, R.C., (1999). System dynamics: A unified approach. John Wily \& Sons, Inc., New York, NY, USA, app. 45-7.

Kenoyer, J.M., (2005). History of brickmaking, Encyclopædia Britannica, "Uncovering the keys to the Lost Indus Cities",Scientific American, 15: 24-33, doi:10.1038/scientificamerican0105-24sp

Kerlinger, F. N. (1977). Foundation of Behavioral Research, 2nd Edition Sign of the Times Publishing Co. Circumati.

Kolade, J.O., (2016). Design Development and Performance Evaluation of Insolating Brickmaking Machine, Master degree Thesis at the Department of Industrial Design, Faculty of Environmental Design, Ahmadu Bello University, Zaria.

Kolawole, R. A., (2017). Design, Construction and Performance Evaluation of a Multiple Sandcrete Blocks Moulding Machine, Doctoral Thesis at the Department of Mechanical Engineering, Faculty of Engineering, Ahmadu Bello University, Zaria.

Millberg, M.I (2010). "How brick is made”. http://www.made.how/com/volume-11 Retried 29/11/11

Nurudeen T.M. (2010). Development of Fireclay Bricks from Kankara Kaolin using Starch and Starch-Clay 
Binders, Department of Chemical Engineering, Ahmadu Bello University Zaria, Nigeria

Rosacometta. M, (1997). Instruction and Specification for Operation and Maintenance of Vibrobloc Model Riley Automation Ltd, Milan, Italy, app: 5-7.

Soraj, K. P., Kmmula V. P and Clever K, (2011), Design and Construction of a Low Brick Making Machine for Producing Fly Ash-Sand-Cement Bricks. International Journal of Manufacturing Science and Engineering. International Science Press. Vol2. No1. January-June 2011. E-mail: kommula@mopipi.ub.bw

Steven B., (2017), BSBG Head of Structures, presents a case study highlighting the principal differences between blockwork and brickwork. http://bsbgltd.com/blog/the-key-differences-between-blockwork-andbrickwork/

Sullayman, U.A.A, (2006). Utilization of Local Raw Materials for the Production of Dense Aluminosilicate Refractory Bricks for Blast Furnaces Using Semi Dry Pressing Techniques. Doctoral Thesis, Department of Industrial Design, Ahmadu Bello University Zaria, Nigeria.

Yakubu S.O. and Umar M.B. (2015). Design, Construction and Testing of a Multipurpose Brick/Block Moulding Machine. American Journal of Engineering Research (AJER),4(2):33-43. 